\title{
Prevalence of Thinness among Santal Preschool Children Using New Body Mass Index Cut-Off Points
}

\author{
Subal Das and Kaushik Bose \\ Department of Anthropology, Vidyasagar University, Midnapore, West Bengal 72110, India \\ Correspondence should be addressed to Kaushik Bose, banda@vsnl.net
}

Received 23 July 2010; Revised 28 October 2010; Accepted 30 November 2010

Academic Editor: Maryna Steyn

Copyright () 2011 S. Das and K. Bose. This is an open access article distributed under the Creative Commons Attribution License, which permits unrestricted use, distribution, and reproduction in any medium, provided the original work is properly cited.

A community-based cross-sectional study was undertaken to determine the prevalence of undernutrition using body mass index (BMI) among 2-6-year Santal preschool children of Purulia District, West Bengal, India. A total of 251 (116 boys and 135 girls) children from 12 villages were measured. Commonly used indicators, that is, weight, height, and BMI, were used to evaluate the nutritional status. More boys (59.5\%) than girls (53.3\%), based on BMI, were undernourished. Significant age differences in weight $\left(F=44.29^{* * *} ; d f=3\right)$, height $\left(F=58.48^{* *} ; d f=3\right)$, and BMI $\left(F=3.52^{* * *} ; d f=3\right)$ among boys were observed. Similarly, significant differences between ages in mean weight $\left(F=56.27^{* * *} ; d f=3\right)$, height $\left(F=64.76^{* * *} ; d f=3\right)$, and BMI $\left(F=2.62^{* *} ; d f=3\right)$ were observed among the girls. The present study revealed that the nutritional status of the preschool children of Santal tribal community of these villages was poor with very high rate of thinness in boys and girls (59.5\% and 53.3\%, resp.).

\section{Introduction}

Health and nutritional status are two crucial and interlinked aspects of human development, which in turn interact with demographic variables in important ways. Malnutrition (a condition that occurs due to the intake of inadequate amount of nutrients leading to insufficient nourishment) continues to be a problem of considerable magnitude in most of the developing countries of the world. Preschool children are one of the most nutritionally vulnerable segments of the population. Nutrition during the first five years has not only an impact on growth and morbidity during childhood, but also acts as a determinant of nutritional status in adolescent and adult life. Global comparative data indicate that contrary to common perception, prevalence of undernutrition ( $a$ deficiency of calories or of one or more essential nutrients) is highest in South Asian children [1].

India has the highest occurrence of childhood malnutrition in the world [2]. Malnutrition underlies 55 percent of all deaths of children younger than five years of age globally [3]. Malnutrition makes a child susceptible to infections and delays recovery, thus increasing mortality and morbidity [4]. It is therefore logical to direct increasing attention to the quality of life of the survivors [5].

According to the 2001 census, the Purulia District of West Bengal, India has a total population of $25,36,516$, out of which $89.93 \%$ are residing in rural areas, and $10.07 \%$ are in urban areas. Out of this total population, $19.22 \%$ belongs to Scheduled Tribes. In West Bengal, Purulia District has the second highest percentage of tribal population (18.3\%) after Jalpaiguri (18.9\%). Santals belong to the ProtoAustraloid group with dark skin colour, sunken nose, and lower forehead. Santals comprise $62.66 \%$ of the total tribal population of Purulia, West Bengal.

There are no data on the nutritional status of Santal preschool children. In view of this, the current study presents the prevalence of undernutrition among 2-6-yearold Scheduled Tribe (Santal) preschool children of Purulia District, West Bengal. The aim of the present study was to evaluate different grades of thinness using age- and sexspecific body mass index (BMI) among Santal preschool children using international cut-off points [6]. 
TABLE 1: BMI $\left(\mathrm{kg} / \mathrm{m}^{2}\right)$ cut-off points for thinness grades III, II, and I for 2-6-year-old children [6].

\begin{tabular}{lcccccc}
\hline Age & \multicolumn{3}{c}{ Boys thinness } & \multicolumn{3}{c}{ Girls thinness } \\
(years) & GD-III & GD-II & GD-I & GD-III & GD-II & GD-I \\
& 16.0 & 17.0 & 18.5 & 16.0 & 17.0 & 18.5 \\
\hline 2 & 13.37 & 14.12 & 15.14 & 13.24 & 13.90 & 14.83 \\
3 & 13.09 & 13.79 & 14.74 & 12.98 & 13.60 & 14.47 \\
4 & 12.86 & 13.52 & 14.43 & 12.73 & 13.34 & 14.19 \\
5 & 12.66 & 13.31 & 14.21 & 12.50 & 13.09 & 13.94 \\
6 & 12.50 & 13.15 & 14.07 & 12.32 & 12.93 & 13.83 \\
\hline
\end{tabular}

All values are in $\mathrm{kg} / \mathrm{m}^{2}$.

\section{Materials and Methods}

This study was a community-based, cross-sectional study conducted at twelve different villages (namely, Bidhakata, Amdiha, Kendberia, Dubrajpur, Gundlubhita, Duhugura, Banglakuli, Tusuliam, Muktipur, Eriyakusum, Moroldih, and Moroldih-2) of Santuri block, Purulia District, that are situated about $250 \mathrm{~km}$ from Kolkata, the capital of West Bengal, India. This study was carried out from November, 2009 to February, 2010. The 251 (116 boys and 135 girls) of age 2-6 years were measured. Data were collected after obtaining the necessary approval from the village authorities. Ethical clearance was obtained from the Vidyasagar University Ethics Committee prior to the commencement of the study. Parents of the children were informed about the objectives of our study before the commencement of measurement. Information on age, ethnicity, and sex were collected using a pretested questionnaire by house-to-house visit following interview and examination. Weight $(\mathrm{kg})$ and height $(\mathrm{cm})$ measurements were taken on each subject by the first author following the standard techniques [7].

Body mass index was computed following internationally accepted standard equation as $(\mathrm{BMI})=$ weight $(\mathrm{kg}) /$ height $\left(\mathrm{m}^{2}\right)$. Nutritional status was evaluated using the age- and sex- specific cut-off points of BMI (Table 1) as described by Cole et al. [6]. Grades III, II, and I of thinness refer to severe, moderate, and mild undernutrition. Technical errors of measurements (TEMs) were found to be within reference values [8] and thus not incorporated in statistical analyses. One-way ANOVA ( $F$-test) was performed to test for age differences in means of weight, height, and BMI. All statistical analyses were undertaken using the SPSS Statistical Package. Statistical significance was set at $P<.05$.

\section{Results}

The overall mean and standard deviation (in parentheses) of weight $(\mathrm{kg})$, height $(\mathrm{cm})$, and Body mass index (BMI in $\mathrm{kg} / \mathrm{m}^{2}$ ) of the 2-6-year Santal tribal children were 14.10 (2.99), 99.18 (11.19), and 14.23 (1.20) among boys and 13.72 (3.31), 98.51 (12.87), and 14.04 (1.07) among girls.

Table 2 presents the age- and sexwise mean and standard deviation of weight $(\mathrm{kg})$, height $(\mathrm{cm})$, and body mass index $\left(\mathrm{BMI}\right.$ in $\mathrm{kg} / \mathrm{m}^{2}$ ) of the 2-6-year Santal tribal children. There were significant mean differences between ages among boys in weight $(F=44.29 ; P<.001)$, height $(F=58.48 ; P<$ $.001)$, and BMI $(F=3.52 ; P<.01)$. Similarly, among girls, significant differences were observed in weight $(F=56.27$, $P<.001)$, height $(F=64.76 ; P<.001)$, and BMI $(F=$ 2.62; $P<.01)$. It was also clear from the Table 2 that there was marked decrease in BMI with increasing age both among boys and among girls except for the age of 6 years among boys.

Table 3 presents the prevalence of thinness among 2-6year Santal tribal children of Purulia, West Bengal. Result revealed that age-combined prevalence of undernutrition (Grade I, II, and III combined) among boys and girls was (59.48\%) and (53.34\%), respectively. It was also observed that initial preschooler girls were more undernourished $(61.9 \%)$ and $(61.3 \%)$ at age of 2 and 3 years than their male counterparts $(55.6 \%)$ and $(55.2 \%)$ of the same age. However, late preschooler boys were more undernourished (55.9\%), $(67.9 \%)$ and $(58.1 \%)$ at age of 4,5 , and 6 years than their female counterparts $(47.6 \%),(42.1 \%)$ and $(51.2 \%)$ of same age. Pervasiveness of grade I thinness was more prevalent followed by grade II and III among boys and girls.

\section{Discussion}

Undernutrition among children and adolescents is a serious public health problem internationally, especially in developing countries [9]. The recent study of Cole et al. [6] has stated that undernutrition is better assessed as thinness (low body mass index for age) than as wasting (low weight for height). Prior to this paper, there were no suitable thinness cut-off points for this age group. These new cut-off points were suggested to encourage direct comparison of trends in child and adolescent thinness worldwide. These cut-off points provide a classification of thinness for public health purposes. It must be mentioned here that these cut-off points were derived from multicentre data from the United States, Great Britain, Hong Kong, and the Netherlands including data from Brazil (developing country). Thus, these cut-off points are valid for use among Indian children including these children (Table 1) [6]. The results of the present study clearly indicated that the nutritional situation of Santal preschool children was poor with high rates of thinness of $59.5 \%$ and $53.3 \%$ in boys and girls, respectively. A noteworthy point was that there exists no significant sex difference in rates of thinness.

Figure 1 presents the overall comparison of the prevalence (\%) of undernutrition using thinness (BMI). Previous studies such as Bauri children (66.2\%) [10], urban slum children (57.4\%) [11], ICDS children (63\%) [12], urban children (60\%) [13], and Bhopal children (58\%) [14] have reported higher prevalence of thinness than the present study (Figure 1). However, few recent studies among rural Bengalee children [15], Orissa children [16], and slum children [17] have reported lower prevalence of 50.7\%, $48.0 \%$, and $51 \%$ of thinness, respectively. Thin children are more likely to grow into thin adults with a low BMI that would have an impact on their work productivity as well as lead to 
TABLE 2: Mean and standard deviation of weight, height, and BMI of 2-6-year Santal tribal children.

\begin{tabular}{|c|c|c|c|c|c|c|c|c|c|c|}
\hline \multirow{2}{*}{$\begin{array}{l}\text { Anthropometric } \\
\text { variables }\end{array}$} & \multicolumn{5}{|c|}{ Boys (116) } & \multicolumn{5}{|c|}{ Girls (135) } \\
\hline & $\begin{array}{c}2 \\
(n=9)\end{array}$ & $\begin{array}{c}3 \\
(n=29)\end{array}$ & $\begin{array}{c}4 \\
(n=19)\end{array}$ & $\begin{array}{c}5 \\
(n=28)\end{array}$ & $\begin{array}{c}6 \\
(n=31)\end{array}$ & $\begin{array}{c}2 \\
(n=21)\end{array}$ & $\begin{array}{c}3 \\
(n=31)\end{array}$ & $\begin{array}{c}4 \\
(n=21)\end{array}$ & $\begin{array}{c}5 \\
(n=19)\end{array}$ & $\begin{array}{c}6 \\
(n=43)\end{array}$ \\
\hline Weight (kg) & $\begin{array}{l}10.72 \\
(2.51)\end{array}$ & $\begin{array}{r}11.54 \\
(1.48)\end{array}$ & $\begin{array}{l}13.63 \\
(1.91)\end{array}$ & $\begin{array}{l}14.52 \\
(1.51)\end{array}$ & $\begin{array}{l}17.37 \\
(2.30)\end{array}$ & $\begin{array}{l}10.26 \\
(1.90)\end{array}$ & $\begin{array}{l}11.13 \\
(1.70)\end{array}$ & $\begin{array}{l}13.45 \\
(2.03)\end{array}$ & $\begin{array}{l}14.79 \\
(2.28)\end{array}$ & $\begin{array}{l}16.94 \\
(2.19)\end{array}$ \\
\hline Height $(\mathrm{cm})$ & $\begin{array}{l}84.43 \\
(9.55)\end{array}$ & $\begin{array}{l}88.75 \\
(5.25)\end{array}$ & $\begin{array}{l}97.31 \\
(7.64)\end{array}$ & $\begin{array}{l}103.16 \\
(4.83)\end{array}$ & $\begin{array}{l}110.75 \\
(6.97)\end{array}$ & $\begin{array}{l}84.49 \\
(9.58)\end{array}$ & $\begin{array}{l}88.23 \\
(6.80)\end{array}$ & $\begin{array}{l}97.59 \\
(8.02)\end{array}$ & $\begin{array}{l}102.91 \\
(7.68)\end{array}$ & $\begin{array}{l}111.26 \\
(6.63)\end{array}$ \\
\hline $\mathrm{BMI}\left(\mathrm{kg} / \mathrm{m}^{2}\right)$ & $\begin{array}{l}14.94 \\
(1.60)\end{array}$ & $\begin{array}{l}14.59 \\
(1.32) \\
\end{array}$ & $\begin{array}{l}14.38 \\
(1.06) \\
\end{array}$ & $\begin{array}{l}13.65 \\
(1.18) \\
\end{array}$ & $\begin{array}{l}14.12 \\
(0.82) \\
\end{array}$ & $\begin{array}{l}14.38 \\
(1.26) \\
\end{array}$ & $\begin{array}{l}14.27 \\
(1.14) \\
\end{array}$ & $\begin{array}{l}14.24 \\
(1.19) \\
\end{array}$ & $\begin{array}{l}13.95 \\
(0.84) \\
\end{array}$ & $\begin{array}{l}13.65 \\
(0.86) \\
\end{array}$ \\
\hline
\end{tabular}

TABLE 3: Prevalence (\%) of thinness by age and sex among Santal children.

\begin{tabular}{lcccccccc}
\hline \multirow{2}{*}{ Age (years) } & \multicolumn{3}{c}{ Boys } & & \multicolumn{3}{c}{ Girls } \\
& Gd-I & Gd-II & Gd-III & Overall & Gd-I & Gd-II & Gd-III & Overall \\
\hline 2 & 22.2 & 22.2 & 11.1 & 55.6 & 28.6 & 23.8 & 9.5 & 61.9 \\
3 & 31.0 & 13.8 & 10.3 & 55.2 & 38.7 & 16.1 & 6.5 & 61.3 \\
4 & 42.1 & 10.5 & 5.3 & 57.9 & 28.6 & 9.5 & 9.5 & 47.6 \\
5 & 32.1 & 17.9 & 17.9 & 67.9 & 31.6 & 5.3 & 5.3 & 42.1 \\
6 & 48.4 & 9.7 & 0.0 & 58.1 & 23.4 & 18.6 & 9.3 & 51.2 \\
\hline Total & 37.1 & 13.8 & 8.62 & 59.5 & 29.6 & 15.6 & 8.15 & 53.3 \\
\hline
\end{tabular}

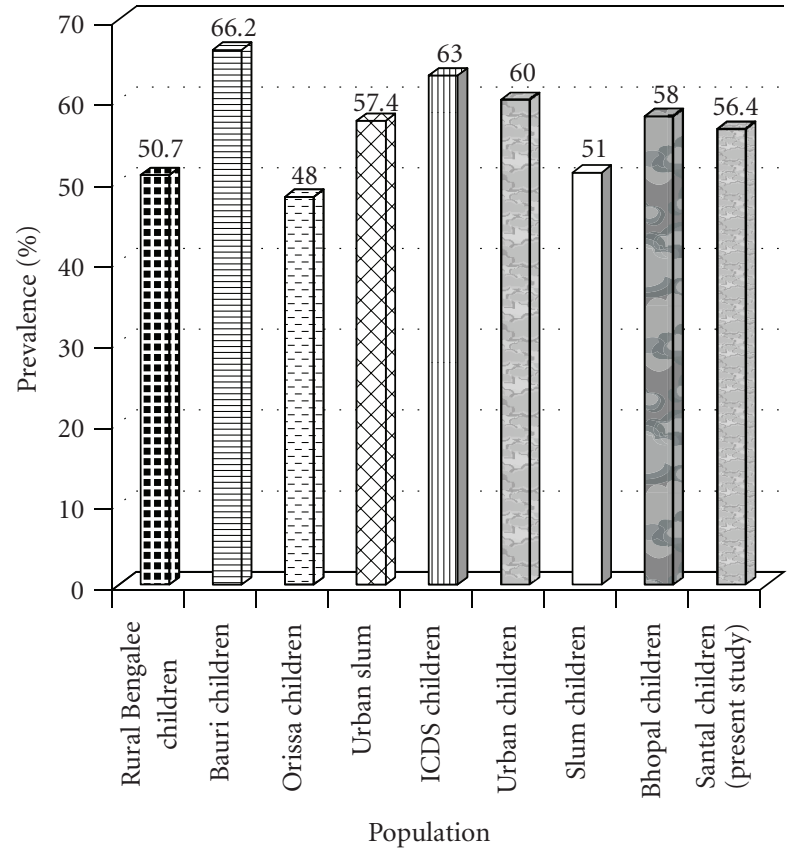

Figure 1: Overall comparison of the prevalence (\%) of thinness among preschool children.

greater rates of morbidity and mortality. The present study revealed that the nutritional status of the preschool children of Santal tribal community of these villages was poor with very high rate of thinness of $59.5 \% \& 53.3 \%$ in boys and girls. To overcome this problem there is an immediate requirement for appropriate steps to be taken to improve nutritional status of this ethnic group in Purulia. It is therefore recommended that nutritional supplementation programmes be initiated within this community.

\section{Acknowledgments}

All participating subjects, villagers, and block authorities are gratefully acknowledged for their cooperation. S. Das received financial assistance in the form of Junior Research Fellowship from University Grants Commission, Government of India (UGC— ref. no. 223/NET-Dec. 2008).

\section{References}

[1] SCN (United Nation Standing Committee on Nutrition), Fifth Report on the World Nutrition Situation: Nutrition for Improved Development Outcomes, SCN, Geneva, Switzerland, 2004.

[2] M. S. Bamji, "Early nutrition and health-Indian perspective," Current Science, vol. 85, no. 8, pp. 1137-1142, 2003.

[3] D. L. Pelletier, "The relationship between child anthropometry and mortality in developing countries: implications for policy, programs and future research," Journal of Nutrition, vol. 124, no. 10, pp. 2047S-2081S, 1994.

[4] S. Chatterjee and S. Saha, "A study on knowledge and practice of mothers regard $\neg$ ing infant feeding and nutritional status of under-five children attending immunization clinic of a medical college," Internet Journal of Nutrition and Wellness, vol. 5, no. 1, 2008.

[5] H. P. S. Sachdev, Assessing Child Malnutrition: Some Basic Issues Nutritional Foundation of India Archives, vol. 156, NFI, New Delhi, India, 1996.

[6] T. J. Cole, K. M. Flegal, D. Nicholls, and A. A. Jackson, "Body mass index cut offs to define thinness in children and adolescents: international survey," British Medical Journal, vol. 335, no. 7612, pp. 194-197, 2007. 
[7] World Health Organization, "Physical status: the use and interpretation of anthropometry," Tech. Rep. 854, World Health Organization, Geneva, Switzerland, 1995.

[8] S. J. Ulijaszek and D. A. Kerr, "Anthropometric measurement error and the assessment of nutritional status," British Journal of Nutrition, vol. 82, pp. 165-177, 1988.

[9] D. L. Pelletier and E. A. Frongillo, "Changes in child survival are strongly associated with changes in malnutrition in developing countries," Journal of Nutrition, vol. 133, no. 1, pp. 107-119, 2003.

[10] S. Das and K. Bose, "Anthropometric characteristics and nutritional status of Bauri pre-school children of Nituria Block, Purulia, West Bengal," Internet Journal of Biological Anthropology, vol. 3, no. 2, 2009.

[11] M. K. Goel, R. Mishra, D. R. Gaur, and A. Das, "Nutrition surveillance in 1-6 years old children in Urban slums of a city in Northern India," Internet Journal of Epidemiology, vol. 5, no. $1,2007$.

[12] K. D. Bhalani and P. V. Kotecha, "Nutritional status and gender difference in the children of less than 5 years of age attending ICDS anganwadis in Vadodra city," Indian Journal of Community Medicine, vol. 27, pp. 124-129, 2002.

[13] I. A. Bhat, S. Amin, and G. N. Shah, "Impact of sociomedical factors on pre-school malnutrition - an appraisal in an urban setting," Indian Journal of Maternal and Child Health, vol. 8, no. 1, pp. 5-8, 1997.

[14] S. K. Ray, P. Roy, S. Deysarkari, A. Lahiri, and B. B. Mukhopadhaya, "A cross sectional study of undernutrition in $0-5$ yrs. age group in an urban community," Indian Journal of Maternal and Child Health, vol. 1, no. 2, pp. 61-62, 1990.

[15] S. Biswas, K. Bose, S. Bisai, and R. Chakraborty, "Prevalence of thinness among rural Bengalee pre-school children in Chapra, Nadia District, West Bengal, India," Malaysian Journal of Nutrition, vol. 15, no. 2, pp. 155-164, 2009.

[16] B. Mishra and S. Mishra, "Nutritional anthropometry and pre-school child feeding practice in working mothers of central Orissa," Studies on Home and Community Science, vol. 1, no. 2, pp. 139-144, 2007.

[17] P. K. Sen, "Nutritional status of under five children in an urban slum community of Calcutta," Indian Journal of Public Health, vol. 38, no. 3, pp. 113-114, 1994. 


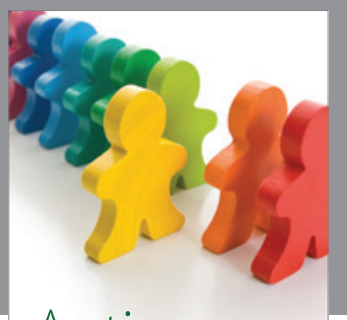

Autism

Research and Treatment
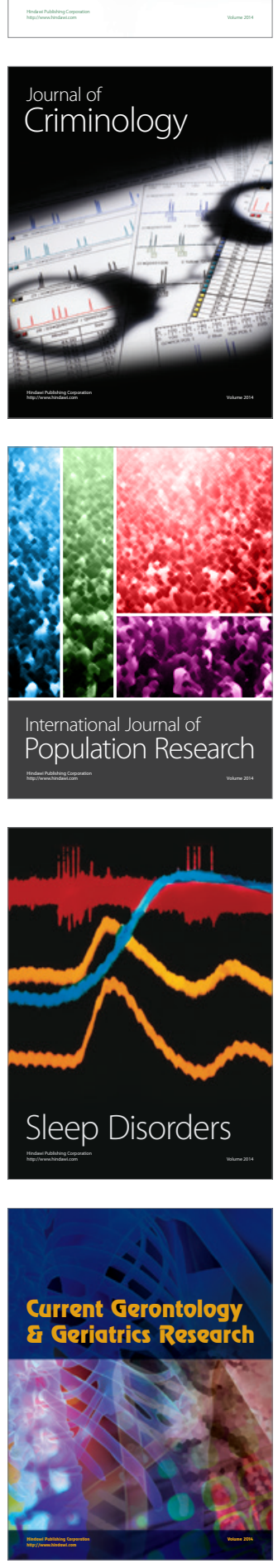
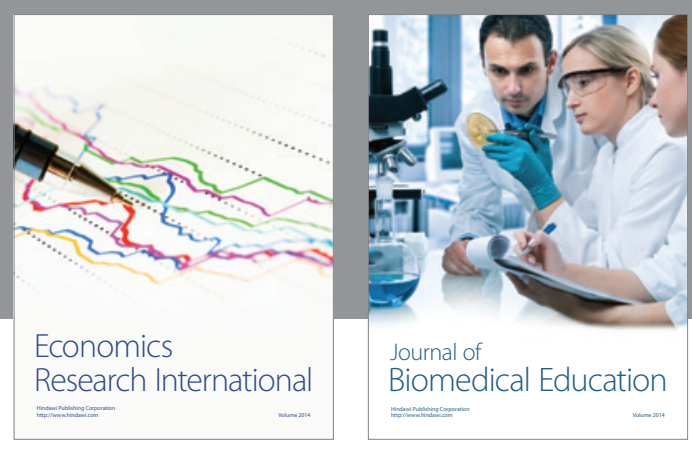

Journal of

Biomedical Education

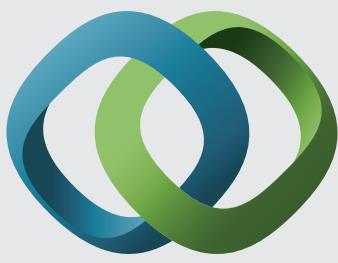

\section{Hindawi}

Submit your manuscripts at

http://www.hindawi.com
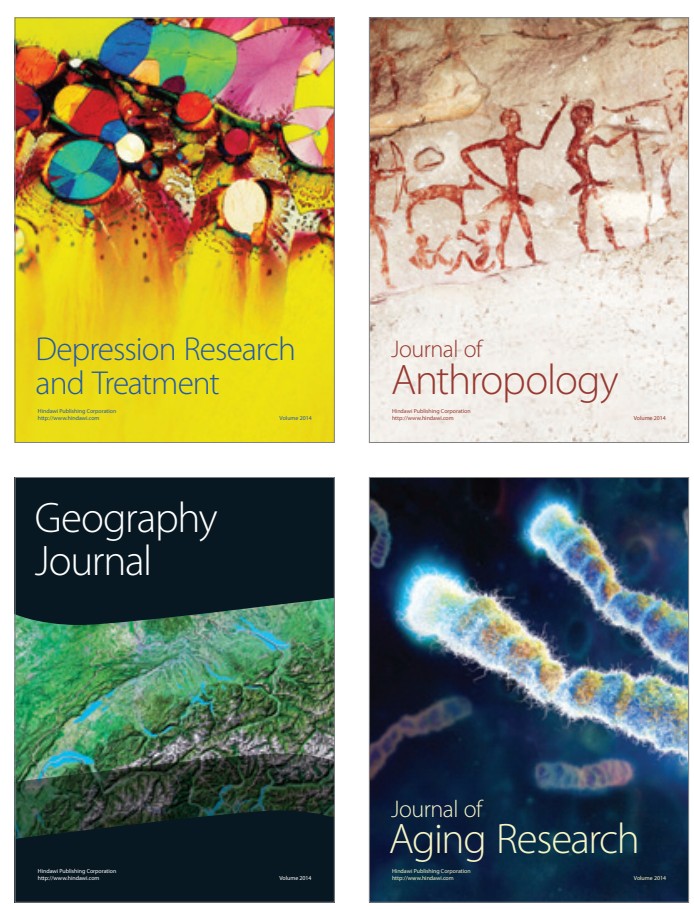

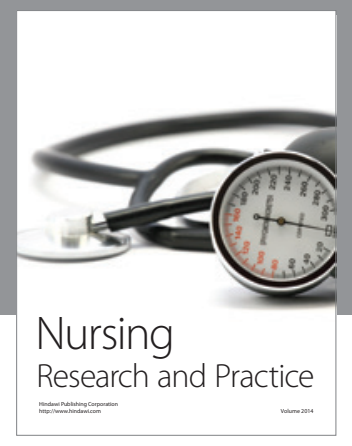

Nursing

Research and Practice

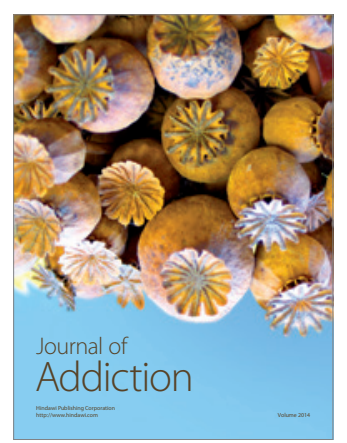

Child Development

Research

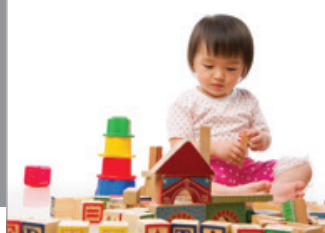

迥
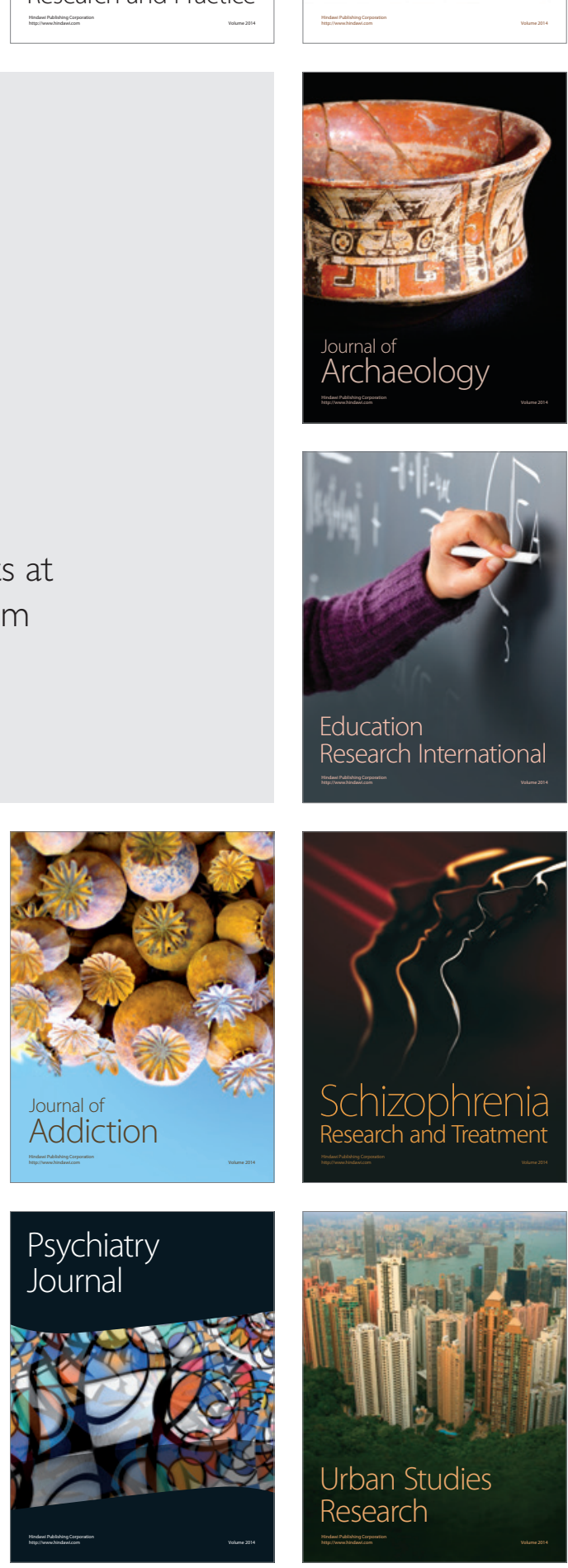